\title{
Comparative metabolism of L-methionine, DL-methionine and DL-2-hydroxy 4-methylthiobutanoic acid by broiler chicks
}

\author{
BY C. LINDA SAUNDERSON \\ Agricultural and Food Research Council's Poultry Research Centre, \\ Roslin, Midlothian EH25 9PS
}

(Received 17 April 1985 - Accepted 22 May 1985)

\begin{abstract}
1. Metabolism, in broiler chicks, of DL-2-hydroxy 4-methylthiobutanoic acid (DL-HMB), DL-methionine and L-methionine was compared in vivo using ${ }^{14} \mathrm{C}$-labelled tracers.

2. The distribution of $L-\left[1-{ }^{14} \mathrm{C}\right]$ methionine and $\mathrm{DL}-\left[1-{ }^{14} \mathrm{C}\right] \mathrm{HMB}$ in the major body tissues was examined for a period of $120 \mathrm{~min}$ after administration.

3. The relative oxidation $\left({ }^{14} \mathrm{CO}_{2}\right.$ exhaled), excretion and incorporation into tissue protein of $L-\left[1-{ }^{14} \mathrm{C}\right]$ methionine, $\mathrm{DL}-\left[1-{ }^{14} \mathrm{C}\right]$ methionine and $\mathrm{DL}-\left[1-{ }^{14} \mathrm{C}\right] \mathrm{HMB}$ were measured in fed birds.

4. Tissue distribution of $\mathrm{L}-\left[1-^{14} \mathrm{C}\right]$ methionine and $\mathrm{DL}-\left[1-{ }^{14} \mathrm{C}\right] \mathrm{HMB}$ differed during $60-90 \mathrm{~min}$ following administration.

5. The production of ${ }^{14} \mathrm{CO}_{2}$ from each of the tracers was similar but excretion of ${ }^{14} \mathrm{C}$-labelled material was very different with the greatest excretion from $\mathrm{DL}-\left[1-{ }^{14} \mathrm{C}\right] \mathrm{HMB}$ and the least from $\mathrm{L}-\left[1-{ }^{14} \mathrm{C}\right]$ methionine.

6. The incorporation of ${ }^{14} \mathrm{C}$ into tissue proteins varied with the tracer given and the tissue examined. Liver and kidney had equivalent incorporation from each of the tracers while other tissues examined showed lower incorporation from $\mathrm{DL}-\left[1-1^{19} \mathrm{C}\right] \mathrm{m}$ ethionine and $\mathrm{DL}-\left[1{ }^{14} \mathrm{C}\right] \mathrm{HMB}$.

7. The results show that DL-HMB, D-methionine and L-methionine are metabolized differently in vivo and that they are excreted in differing proportions. There is also a difference in the ability of each to act as a precursor for protein synthesis in tissues other than liver.
\end{abstract}

The essential amino acid methionine is most often the first-limiting amino acid of commercially-produced poultry feedstuffs. Supplementary methionine is added either as DL-methionine, as the hydroxy acid, 2-hydroxy 4-methylthiobutanoic acid (Alimet; HMB) or as the calcium salt of the hydroxy acid, methionine hydroxy analogue (MHA).

It is a number of years since MHA was shown to serve as a source of methionine for poultry (Bird, 1952; Gordon \& Sizer, 1955). Numerous studies since then have attempted to determine the efficiency with which HMB (in the form of the free acid or the analogue) can replace L- and DL-methionine in the diet. In these studies, the effects on growth or egg production of giving supplements of methionine (L or DL) or HMB to birds given basal methionine-deficient diets were usually measured. Of the studies where practical (compound) feedstuffs were used, some show no difference between HMB and L- or DL-methionine (e.g. Gordon \& Sizer, 1955; Reid et al. 1982) while others show HMB to be less effective than L- or DL-methionine for supporting growth or egg production (e.g. Smith, 1966; Tipton et al. 1966). Unfortunately the basal, 'low-methionine' diets used in these studies differ both in composition and degree of methionine deficiency. Studies in which crystalline amino acids (purified diets) are the only source of nitrogen, consistently show that HMB cannot totally replace DL-methionine in the diet (Featherston \& Horn, 1974; Katz \& Baker, 1975a; Christensen et al. 1980; Boebel \& Baker, 1982; van Weerden et al. 1982).

There have been relatively few studies carried out to examine the metabolism of HMB in the chick. D- and L-HMB and D-methionine are converted to L-methionine in the tissues of many animals. Liver and kidney appear to be the major organs performing these transformations both in chicks (Gordon \& Sizer, 1955) and in rats (Baker, 1952; Langer, 1965).

Dibner \& Knight (1984a) have investigated the enzymes which catalyse the oxidation of 
HMB to the corresponding $\alpha$-keto acid, 2-keto 4-methylthiobutanoic acid (KMB); the necessary first stage in conversion of HMB to L-methionine. The D- and L-isomers of HMB are oxidized by different enzymes and in different cellular and tissue locations. The D-hydroxy acid dehydrogenase is not only active in the mitochondrial fractions of liver and kidney but also in skeletal muscle, intestinal mucosa, spleen and brain. This suggests that the two isomers of HMB may differ in the efficiency with which they are used by different tissues.

Gordon \& Sizer (1965), using DL-HMB and L-methionine labelled with ${ }^{35} \mathrm{~S}$, found that the radioactivity was incorporated equally well into liver protein and was distributed equally in the blood plasma and excreta (after $24 \mathrm{~h}$ ) from either material. Dibner (1983), working with isolated chick hepatocytes, found no difference in the rate of incorporation of labelled HMB or methionine into liver protein. Such studies purport to show equivalence of HMB and L-methionine as a precursor for protein synthesis in spite of the fact that results of many feeding trials are contrary to this hypothesis.

Larbier \& Perrot (1984) have compared the distribution of ${ }^{14} \mathrm{C}$-labelled L-methionine, DL-methionine and DL-HMB in liver, breast muscle and blood plasma of young chicks for $24 \mathrm{~h}$ following intraperitoneal injection. They found that more ${ }^{14} \mathrm{C}$ from $\mathrm{DL}-\mathrm{methionine}$ and DL-HMB was present in the 'free pools' (i.e. acid-soluble cell extracts) of all three tissues. The proteins of muscle contained less ${ }^{14} \mathrm{C}$ when $\mathrm{L}-\left[1-{ }^{14} \mathrm{C}\right] \mathrm{HMB}$ was given than from either $\mathrm{L}$ or $\mathrm{DL}-\left[1{ }^{14} \mathrm{C}\right]$ methionine. However, in plasma and to a greater extent in liver the proteins were more highly labelled by $\mathrm{DL}-\left[1{ }^{14} \mathrm{C}\right] \mathrm{HMB}$ than $\mathrm{L}-$ or DL- $\left[1-{ }^{14} \mathrm{C}\right]$ methionine.

The purpose of the work reported here was to investigate the metabolism in vivo of HMB in young broiler chicks and to examine its ability to replace methionine for protein synthesis in growing tissues. The effectiveness of HMB was compared with both L-methionine and DL-methionine. Preliminary reports of this work have appeared elsewhere (Saunderson $1983 a, b)$.

\section{MATERIALS AND METHODS}

DL- $\left[1-{ }^{14} \mathrm{C}\right]$ methionine, $\mathrm{L}-\left[1-{ }^{14} \mathrm{C}\right]$ methionine and $\mathrm{NaH}^{14} \mathrm{CO}_{3}$ were obtained from Amersham International plc, Amersham, Bucks. Specific activity of DL-[1-14C]methionine was $401 \mu \mathrm{Ci} / \mathrm{mg}$ and of $\mathrm{L}-\left[1-{ }^{14} \mathrm{C}\right]$ methionine between 338 and $364 \mu \mathrm{Ci} / \mathrm{mg}$ (depending on the batch). Radiochemical purity of both materials was $98 \%$.

DL- $\left[1-{ }^{14} \mathrm{C}\right]$ HMB was provided by Monsanto Co, St Louis, Missouri, USA and the specific activity of the material received was $35 \cdot 1 \mu \mathrm{Ci} / \mathrm{mg}$ and the radiochemical purity was $90 \%$. No attempt was made to purify this material further due to lack of facilities. Although HMB polymerizes spontaneously in concentrated solution (Koban \& Koberstein, 1984), it is unlikely that the DL-[1- $\left.{ }^{14} \mathrm{C}\right] \mathrm{HMB}$ supplied contained any form other than the monomer as it was in dilute solution.

Fisofluor 1 and Fisofluor 3 liquid scintillation cocktails and Fisosolve tissue solubilizer were obtained from Fisons Ltd, Loughborough. Ethanolamine, 2-methoxy ethanol and toluene ('Scintran' grade) and Dowex $1 \times 8 \mathrm{Cl}$-form ion-exchange resin were obtained from BDH Chemicals Ltd, Poole, Dorset.

L-methionine, DL-methionine and DL-HMB ( $\mathrm{Ca}^{2+}$ salt) were obtained from Sigma Chemical Co. Ltd, Poole, Dorset. All other chemicals were of analytical grade.

\section{Animals and husbandry}

Broiler chicks were obtained at 1-d-old from D. B. Marshall Ltd, Newbridge, Midlothian or from stock produced at the Poultry Research Centre.

All birds were housed in a heated battery brooder from 1-d-old until used for experiment (14-32 d). Birds were given free access to food (chick starter ration; Bolton \& Blair, 1974) and to water at all times. 


\section{Metabolism chamber}

Oxidation and excretion of administered ${ }^{14} \mathrm{C}$-labelled materials were measured in individual birds using a metabolism chamber. This consisted of a Perspex animal chamber $(300 \times 300 \times 300 \mathrm{~mm})$ with a sealable lid. The cage floor was a wire platform raised over a removable Perspex tray. Air was drawn through the chamber by means of a small electric pump at a flow-rate of 2.5-3 litres/min. Air from the chamber was passed through a tube, containing small glass beads, in an ice bath. This creates a large cold surface which removes most of the exhaled water vapour which would otherwise reduce the efficiency of collecting and counting exhaled ${ }^{14} \mathrm{CO}_{2}$. The dried air is then passed through a solution of ethanolamine2-methoxyethanol $(1: 2)$ to trap $\mathrm{CO}_{2}$. Tests using ${ }^{14} \mathrm{CO}_{2}$ (acidified $\mathrm{NaH}^{14} \mathrm{CO}_{3}$ solution) released into the empty chamber showed that all radioactivity $(>97 \%)$ was collected within $1 \mathrm{~h}$ and $65-80 \%$ of this was present in the collecting solution within $30 \mathrm{~min}$. When a bird was placed in the chamber during such a test, $5-8 \%$ of the ${ }^{14} \mathrm{CO}_{2}$ was lost from the trapping solution but could be recovered in a second tube of solution. This implies that the values for oxidation of L-methionine, DL-methionine and DL-HMB may be underestimated by $5-8 \%$ of the total. However, as all compounds are affected in the same way the conclusions drawn from the work are unchanged.

\section{Experimental procedure}

Tissue distribution of administered $\mathrm{L}-\left[1-{ }^{14} \mathrm{C}\right]$ methionine and $\mathrm{DL}-\left[1-{ }^{14} \mathrm{C}\right] H M B$. Birds $(400-600 \mathrm{~g}$ body-weight) were randomly selected, weighed and injected intraperitoneally with $2 \cdot 5 \mu \mathrm{Ci} / \mathrm{kg}$ body-weight of $\mathrm{L}-\left[1-{ }^{14} \mathrm{C}\right]$ methionine or DL- $\left[1-{ }^{14} \mathrm{C}\right] \mathrm{HMB}$. At a set time after injection $(10,30,60,90,120 \mathrm{~min})$ one bird was chosen and a blood sample taken from a wing vein. The bird was then killed by cervical dislocation and tissue samples rapidly excised and stored at $-20^{\circ}$. Tissue samples were taken from breast (pectoralis major) and leg muscles (gastrocnemius), liver, kidney, heart, brain, skin, pancreas and intestine (ileum and jejunum). Radioactivity in perchloric acid (PCA)-precipitable and soluble tissue fractions and in protein-free plasma was measured as described later.

Oxidation and excretion of administered $\mathrm{L}-\left[1-{ }^{14} \mathrm{C}\right]$ methionine, $\mathrm{DL}-\left[1-{ }^{14} \mathrm{C}\right]$ methionine and DL- $\left[1-{ }^{14} \mathrm{C}\right] M H A$. A bird was chosen at random, weighed and given $5 \mu \mathrm{Ci} / \mathrm{kg}$ body-weight of $\mathrm{L}-\left[1-{ }^{14} \mathrm{C}\right]$ methionine, DL- $\left[1-{ }^{14} \mathrm{C}\right]$ methionine or $\mathrm{DL}-\left[1-{ }^{14} \mathrm{C}\right] \mathrm{HMB}$ by intraperitoneal injection. Immediately after injection the bird was placed in the metabolism chamber, the lid sealed and the pump switched on. While in the chamber all birds had free access to food and water. The ethanolamine-2-methoxyethanol solution $(10 \mathrm{ml})$ was changed every hour during the experiment. After $6 \mathrm{~h}$, the bird was removed from the chamber, killed by cervical dislocation and tissue samples rapidly removed and frozen. The excreta were collected and counted for radioactivity as described later.

Preparation of radioactive samples for counting. Tissue samples $(1 \mathrm{~g})$ were thawed, homogenized in $4 \mathrm{ml}$ ice-cold PCA solution $(1 \cdot 2 \mathrm{M})$ then centrifuged at $6000 \mathrm{~g}$ for $15 \mathrm{~min}$. Portions of the supernatant fraction were counted for radioactivity in Fisofluor 1. Precipitates were washed with water, then solubilized using Fisosolve and counted in Fisofluor 3. Blood samples were centrifuged at $2000 \mathrm{~g}$ for $10 \mathrm{~min}$. Plasma was removed and deproteinized with an equal volume of sulphosalicylic acid solution (50 g/1). After removing the precipitated proteins by centrifugation, plasma radioactivity was measured in Fisofluor 1.

Excreta collected in the metabolism chamber were thoroughly mixed with dilute hydrochloric acid to a known volume $(50-150 \mathrm{ml})$. Solid material was removed by centrifugation and a portion of the supernatant fluid was counted for radioactivity. The 


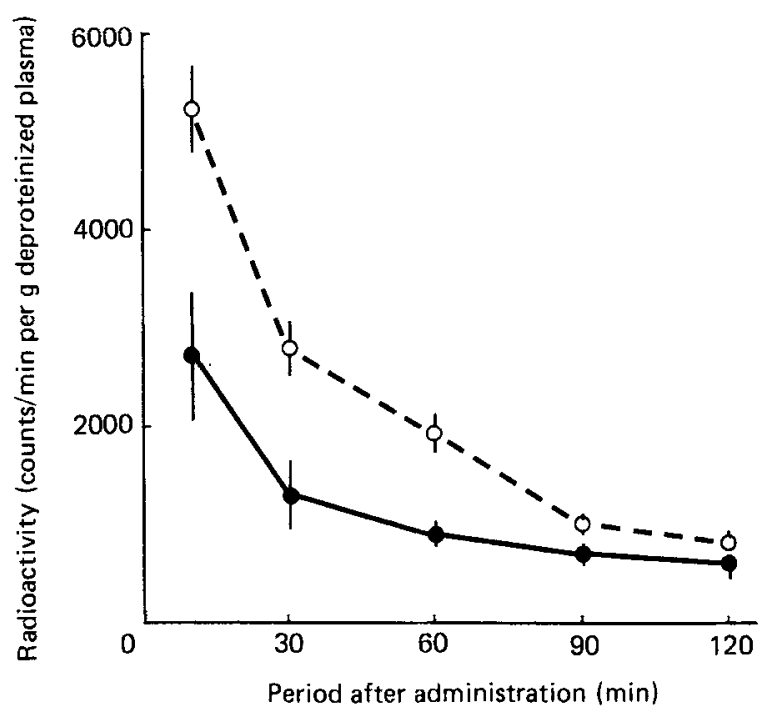

Fig. 1. Distribution of ${ }^{14} \mathrm{C}$ from $\mathrm{L}-\left[1-{ }^{14} \mathrm{C}\right]$ methionine and $\mathrm{DL}-\left[1-^{14} \mathrm{C}\right]$ 2-hydroxy 4 -methylthiobutanoic acid (HMB) in deproteinized blood plasma. Each point represents the mean of three values, with their standard errors represented by vertical bars. () $\mathrm{L}-\left[1-{ }^{14} \mathrm{C}\right]$ methionine administered at $0 \mathrm{~min},(\mathrm{O})$ $\mathrm{DL}-\left[1{ }^{-14} \mathrm{C}\right]+\mathrm{HMB}$ administered at $0 \mathrm{~min}$.

efficiency of counting the excreta extracts was checked by internal standard and was rarely below $90 \%$.

${ }^{14} \mathrm{CO}_{2}$ in ethanolamine-2-methoxyethanol was counted using 2-methoxyethanol-toluene solution containing 2,5-diphenyloxazole as described by Jeffay \& Alvarez (1961).

Liquid scintillation counting of radioactive samples was carried out using an LKB 1216 liquid-scintillation counter. All samples were counted in 5-ml plastic minivials.

Chromatography of ${ }^{14} \mathrm{C}$-labelled components of excretion. Separation of ${ }^{14} \mathrm{C}$-labelled metabolites in excreta extracts was carried out using a method adapted from Spydevold (1979) and La Noue et al. (1970). Chromatography was performed using a Dowex 1 formate column $(6 \times 500 \mathrm{~mm}$; Dowex $1 \times 8,200-400 \mathrm{mesh})$ equilibrated with water. The sample was applied in $10 \mathrm{ml}$ water. Components were eluted with $40 \mathrm{ml}$ water followed by $60 \mathrm{ml}$ $2 \mathrm{M}$-ammonium formate, $\mathrm{pH} 2 \cdot 7$, at a flow-rate of $1 \mathrm{ml} / \mathrm{min}$ (using a high pressure pump) and collected in $2-\mathrm{ml}$ fractions.

\section{Statistical analysis}

The effects of chick source, age and body-weight on the results was evaluated by analysis of variance.

Student's $t$ test was used initially to compare the effects of administering labelled compounds on ${ }^{14} \mathrm{CO}_{2}$ production, ${ }^{14} \mathrm{C}$ in excreta and ${ }^{14} \mathrm{C}$ incorporation into tissue proteins. There was evidence of non-normality (as judged by correlation with the order statistic from a normal distribution) in the values for ${ }^{14} \mathrm{C}$ in excreta and in heart, skin and brain tissue proteins. There seemed to be some chance in heart tissue that this reflected contamination by blood, although every effort was made to avoid this, but in general, no explanation for the non-normal distributions could be found.

Use of the non-parametric Mann-Whitney test (Table 4, p. 630) caused only two major changes in the assessment of treatment comparisons. Both the difference between L$\left[1-{ }^{14} \mathrm{C}\right]$ methionine and DL- $\left[1-{ }^{14} \mathrm{C}\right]$ methionine in heart and L- $\left[1-{ }^{14} \mathrm{C}\right]$ methionine and DL- 


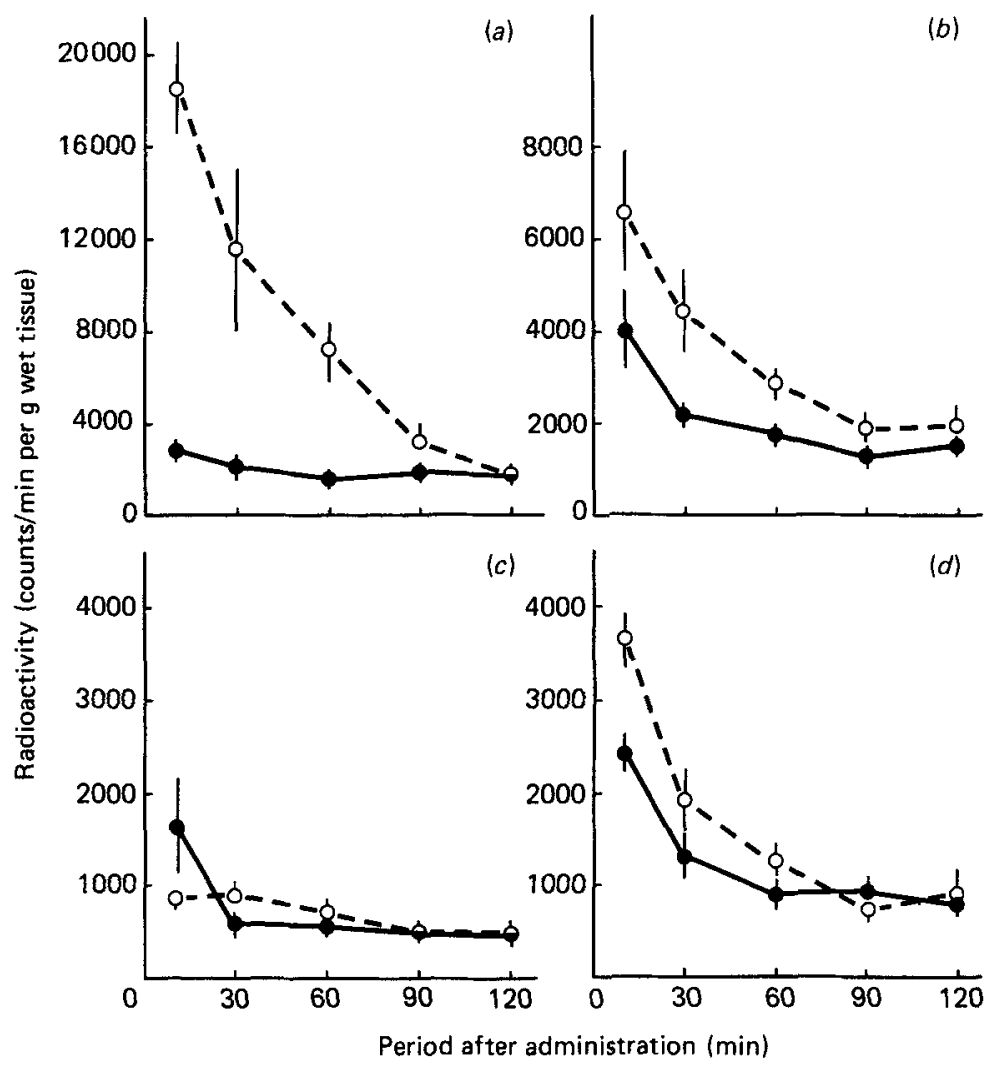

Fig. 2. Distribution of ${ }^{14} \mathrm{C}$ from $\mathrm{L}-\left[1-{ }^{14} \mathrm{C}\right]$ methionine and $\mathrm{DL}-\left[1-{ }^{14} \mathrm{C}\right] 2$-hydroxy 4 -methylthiobutanoic acid (HMB) in perchloric acid-soluble fractions of tissues. $(a)$ Kidney, $(b)$ liver, $(c)$ breast muscle, $(d)$ heart muscle (washed free of blood). Each point is the mean of three measurements with their standard errors represented by vertical bars. (O) $\mathrm{L}-\left[1-{ }^{14} \mathrm{C}\right]$ methionine administered at $0 \mathrm{~min},(\mathrm{O}) \mathrm{DL}-\left[1-{ }^{14} \mathrm{C}\right] \mathrm{HMB}$ administered at $0 \mathrm{~min}$.

$\left[1{ }^{14} \mathrm{C}\right] \mathrm{HMB}$ in brain tissue were now judged to be significant (see Table 4). In other cases the use of the non-parametric test only affected the level of significance. In the values for ${ }^{14} \mathrm{C}$ excretion the treatment effects were so large that the non-parametric test and the $t$ test led to the same conclusions.

\section{RESULTS}

Distribution of ${ }^{14} \mathrm{C}$ in the blood plasma over $120 \mathrm{~min}$ following injection of $\mathrm{DL}-\left[1{ }^{14} \mathrm{C}\right] \mathrm{HMB}$ or $\mathrm{L}-\left[1-{ }^{14} \mathrm{C}\right]$ methionine is shown in Fig. 1. Both L-methionine and DL-HMB appeared rapidly in the plasma but the radioactivity from DL-HMB disappeared more slowly than that from $\mathrm{L}$-methionine. The presence of radioactivity in the PCA-soluble fractions of tissues was also examined over $2 \mathrm{~h}$ following administration of DL- $\left[1-{ }^{14} \mathrm{C}\right] \mathrm{HMB}$ or $\mathrm{L}-[1$ ${ }^{14} \mathrm{C}$ ]methionine (Fig. 2). A large amount of radioactivity was found in the kidney following $\mathrm{DL}-\left[1-{ }^{14} \mathrm{C}\right] \mathrm{HMB}$ injection. This did not happen when $\mathrm{L}-\left[1-{ }^{14} \mathrm{C}\right] \mathrm{methionine}$ was given. In liver tissue there was no large accumulation of ${ }^{14} \mathrm{C}$ from $\mathrm{DL}-\left[1-{ }^{14} \mathrm{C}\right] \mathrm{HMB}$, although the radioactivity from $H M B$ was always higher than that from $\mathrm{L}-\left[1-{ }^{14} \mathrm{C}\right]$ methionine (Fig. $2(b)$ ).

There was very little difference between $\mathrm{L}-\left[1-{ }^{14} \mathrm{C}\right]$ methionine and $\mathrm{DL}-\left[1-{ }^{14} \mathrm{C}\right] \mathrm{HMB}$ in the 
Table $1 .{ }^{14} \mathrm{C}$ labelling in perchloric acid $(P C A)$-soluble and PCA-precipitable fractions of tissues $2 \mathrm{~h}$ after administration of $L-\left[1-{ }^{14} \mathrm{C}\right]$ methionine or $D L-\left[1-{ }^{14} C\right]$ 2-hydroxy 4-methylthiobutanoic acid $(H M B)$

(Values are given in counts/min per $\mathbf{g}$ wet tissue and are means for duplicate measurements on three different birds)

\begin{tabular}{lccccc}
\hline & \multicolumn{2}{c}{ L-[1-14C]methionine } & & \multicolumn{2}{c}{ DL-(1-14C]HMB } \\
\cline { 2 - 3 } \cline { 5 - 6 } Tissue & PCA-soluble & PCA-precipitable & & PCA-soluble & PCA-precipitable \\
\hline Breast muscle & 420 & 1690 & & 453 & 911 \\
Leg muscle & 647 & 2214 & & 554 & 1685 \\
Liver & 1504 & 6562 & & 1941 & 7993 \\
Kidney & 1856 & 5213 & & 1875 & 4913 \\
Heart muscle & 818 & 3571 & & 929 & 2255 \\
Skin & 968 & 2411 & & 740 & 1149 \\
Brain & 504 & 2232 & & 399 & 1106 \\
Intestine & 2230 & 14141 & & 2202 & 3695 \\
Pancreas & 2393 & 26075 & & 1055 & 10364 \\
\hline \hline
\end{tabular}

radioactivity present in PCA-soluble fractions of breast and heart muscle (Fig. 2(c) and (d)) over the $2 \mathrm{~h}$ following administration. Other tissues examined, leg muscle, skin, pancreas, intestine and brain, also showed no difference between $\mathrm{L}-\left[1-{ }^{14} \mathrm{C}\right]$ methionine and DL$\left[1-{ }^{14} \mathrm{C}\right] \mathrm{HMB}$. Table 1 shows ${ }^{14} \mathrm{C}$ in PCA-soluble and PCA-precipitable fractions of tissues at $2 \mathrm{~h}$ after administration of the tracers. These results demonstrate that $\mathrm{L}-\left[1-{ }^{14} \mathrm{C}\right]$ methionine and $\mathrm{DL}-\left[1-{ }^{14} \mathrm{C}\right] \mathrm{HMB}$ are both accessible to all tissues examined, but there are differences in distribution of ${ }^{14} \mathrm{C}$ from these two materials in blood plasma, liver and kidney over the 60-90 min following administration. The gradual decline of DL- $\left[1-{ }^{14} \mathrm{C}\right] \mathrm{HMB}$-derived radioactivity, in the PCA-soluble fractions, to reach levels equal to those from L-[1${ }^{14} \mathrm{C}$ ]methionine after about $2 \mathrm{~h}$ (or less) indicates little about what becomes of the HMB or in what form the radioactivity is present during this time.

When the incorporation of ${ }^{14} \mathrm{C}$ from $\mathrm{DL}-\left[1-{ }^{14} \mathrm{C}\right] \mathrm{HMB}$ or $\mathrm{L}-\left[1-{ }^{14} \mathrm{C}\right]$ methionine into tissue proteins (PCA-precipitable fraction) was examined, differences between tissues and the two precursors were evident (Fig. 3). In liver and kidney, the amount of ${ }^{14} \mathrm{C}$ in the tissue proteins was the same whether $\mathrm{L}-\left[1-{ }^{14} \mathrm{C}\right]$ methionine or $\mathrm{DL}-\left[1-{ }^{14} \mathrm{C}\right] \mathrm{HMB}$ was administered, except possibly at the earliest time point $(10 \mathrm{~min})$. Since DL-HMB must first be converted to L-methionine before incorporation into protein, a small 'lag' period in DL- $\left[1-{ }^{14} \mathrm{C}\right] \mathrm{HMB}-$ derived ${ }^{14} \mathrm{C}$ reaching tissue protein would be expected.

The other tissues examined all behaved in a similar way towards $\mathrm{L}-\left[1{ }^{-14} \mathrm{C}\right]$ methionine and to DL- $\left[1-{ }^{14} \mathrm{C}\right] \mathrm{HMB}$. Examples are shown for breast and heart muscles in Fig. 3(c) and $(d)$. Incorporation from $\mathrm{DL}-\left[1^{14} \mathrm{C}\right] \mathrm{HMB}$ was lower than from $\mathrm{L}-\left[1^{-14} \mathrm{C}\right]$ methionine at all times examined. Although ${ }^{14} \mathrm{C}$ in PCA-soluble fractions of the tissues was about the same with either of the two ${ }^{14} \mathrm{C}$-labelled precursors, there was not an equivalent amount of ${ }^{14} \mathrm{C}$ incorporation into protein. This indicates that much of the ${ }^{14} \mathrm{C}$ from administered DL$\left[1-{ }^{14} \mathrm{C}\right] \mathrm{HMB}$ was not present in these tissues as methionine or cysteine.

To investigate further the differences in metabolism of methionine and HMB by the body tissues, oxidation, excretion and tissue incorporation of administered L- and DL- $[1-$ $\left.{ }^{14} \mathrm{C}\right]$ methionine and DL- $\left[1-{ }^{14} \mathrm{C}\right] \mathrm{HMB}$ were measured. The use of $\left[1-{ }^{14} \mathrm{C}\right]$-labelled materials has two advantages. Firstly, ${ }^{14} \mathrm{CO}_{2}$ exhaled will be a relative measure of the oxidation of the molecule. Secondly, on removal of the carboxyl group $\left(\right.$ as ${ }^{14} \mathrm{CO}_{2}$ ) the materials are effectively destroyed as a source of methionine or cysteine for protein synthesis. It is very 


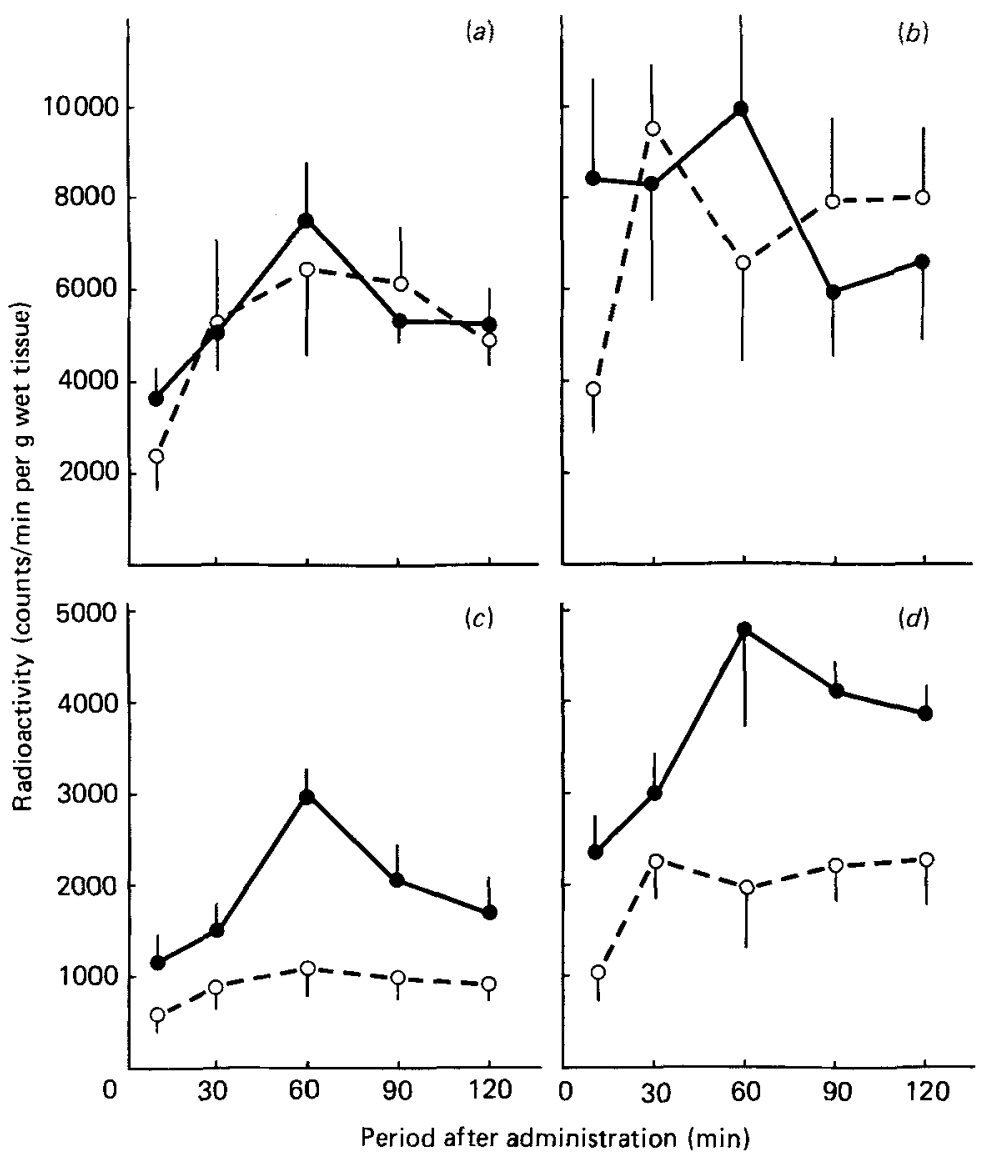

Fig. 3. Incorporation of ${ }^{14} \mathrm{C}$ from $\mathrm{L}-\left[1-{ }^{14} \mathrm{C}\right]$ methionine and $\mathrm{DL}-\left[1{ }^{14} \mathrm{C}\right]$ 2-hydroxy 4-methylthiobutanoic acid (HMB) in perchloric acid-precipitable fractions of tissues. (a) Kidney, $(b)$ liver, $(c)$ breast muscle, (d) heart muscle. Each point is the mean of three measurements with their standard errors represented by vertical bars. $(\mathrm{O}), \mathrm{L}-\left[1-{ }^{14} \mathrm{C}\right]$ methionine administered at $0 \mathrm{~min} ;(\mathrm{O}), \mathrm{DL}-\left[1-{ }^{14} \mathrm{C}\right] \mathrm{HMB}$ administered at $0 \mathrm{~min}$.

unlikely that any of the ${ }^{14} \mathrm{CO}_{2}$ released would be recycled into amino acids. Metabolites of $\mathrm{L}-, \mathrm{DL}-\left[1-{ }^{14} \mathrm{C}\right]$ methionine or $\mathrm{DL}-\left[1-{ }^{14} \mathrm{C}\right] \mathrm{HMB}$ which have not undergone decarboxylation will either be excreted via the urine or retained in the tissue proteins as methionine and cysteine or in cytoplasmic pools (methionine, cysteine, S-adenosyl methionine, 2-keto 4-methylthiobutyrate, etc.). Thus the partitioning of the tracer materials in the body can be examined and compared. ${ }^{14} \mathrm{CO}_{2}$ produced will represent oxidation, ${ }^{14} \mathrm{C}$ in excreta will represent other losses from the system and incorporation of ${ }^{14} \mathrm{C}$ into protein will represent utilization.

In all experiments, the source of 1-d-old chicks, the age of the bird used (14-32 d) or its body-weight did not affect the results.

The release of ${ }^{14} \mathrm{CO}_{2}$ and the excretion of ${ }^{14} \mathrm{C}$-labelled material by birds given $\mathrm{L}$ - or DL- $\left[1-{ }^{14} \mathrm{C}\right]$ methionine or DL- $\left[1-{ }^{14} \mathrm{C}\right] \mathrm{HMB}$ are shown in Table 2 . The oxidation of DLmethionine appeared to be higher than either L-methionine or DL-HMB and the statistical analysis confirms this for the comparison of $\mathrm{L}-\left[1-{ }^{14} \mathrm{C}\right]$ methionine and $\mathrm{DL}-\left[1-{ }^{14} \mathrm{C}\right] \mathrm{methionine}$ (see Table 4, p. 630).

Excretion of ${ }^{14} \mathrm{C}$ from the three tracers contrasts with oxidation as birds excreted the three 
Table 2. Production of ${ }^{14} \mathrm{CO}_{2}$ and excretion of ${ }^{14} \mathrm{C}$ material from $\mathrm{L}-\left[1-{ }^{14} \mathrm{C}\right]$ methionine, $D L-\left[1-{ }^{14} C\right]$ methionine and $D L-\left[1-{ }^{14} C\right] 2-h y d r o x y$ 4-methylthiobutanoic acid $(H M B)$ over $6 \mathrm{~h}$ after adminstration (\% given dose)

(Mean values with their standard errors for eight observations; statistical comparisons are shown in Table 4, p. 630)

\begin{tabular}{|c|c|c|c|c|}
\hline \multirow[b]{2}{*}{ Material administered } & \multicolumn{2}{|c|}{${ }^{14} \mathrm{CO}_{2}$ produced } & \multicolumn{2}{|c|}{${ }^{14} \mathrm{C}$ in excreta extract } \\
\hline & Mean & $\mathrm{SE}$ & Mean & SE \\
\hline $\mathrm{L}-\left[1-{ }^{14} \mathrm{C}\right]$ methionine & $4 \cdot 27$ & 0.459 & 1.88 & $0 \cdot 114$ \\
\hline $\mathrm{DL}-\left[1-{ }^{14} \mathrm{C}\right]$ methionine & $5 \cdot 51$ & 0.293 & 9.59 & 0.513 \\
\hline DL- $\left[1{ }^{-14} \mathrm{C}\right] \mathrm{HMB}$ & $5 \cdot 04$ & 0.751 & $20 \cdot 99$ & 1.009 \\
\hline
\end{tabular}

materials in very different proportions. Little of the ${ }^{14} \mathrm{C}$ from $\mathrm{L}-\left[1-{ }^{14} \mathrm{C}\right]$ methionine was excreted, but a substantial amount of ${ }^{14} \mathrm{C}$ from $\mathrm{DL}-\left[1{ }^{-14} \mathrm{C}\right]$ methionine and an even greater amount of ${ }^{14} \mathrm{C}$ from $\mathrm{DL}-\left[1{ }^{14} \mathrm{C}\right] \mathrm{HMB}$ appeared in the excreta.

It is possible that the impurities $(10 \%)$ in the DL- $\left[1-{ }^{14} \mathrm{C}\right] \mathrm{HMB}$ preparation used led to the high value of ${ }^{14} \mathrm{C}$ in the excreta compared with $\mathrm{DL}-\left[1-{ }^{14} \mathrm{C}\right]$ methionine and $\mathrm{L}-\left[1-{ }^{14} \mathrm{C}\right]$ methionine (impurities $2 \%$ ). In an attempt to clarify this, an examination of the ${ }^{14} \mathrm{C}$-labelled components in excreta extracts was made. Separation of the ${ }^{14} \mathrm{C}$ components by Dowex chromatography is shown in Fig. 4. Chromatograms of the materials injected are included for comparison. (Samples applied to the column were adjusted to contain the same levels of radioactivity, therefore they represent different amounts of excreta extracts.) Also there was some variation between birds in the relative proportions of each of the components in the excreta from any one compound thus the chromatograms show average peak heights for a number of birds (three to five). Results show four components in excreta extracts that are common to all three compounds. The component at fraction no. 9 has similar chromatographic properties to methionine while a small amount of material that behaves like DL- $\left[1-{ }^{14} \mathrm{C}\right] \mathrm{HMB}$ appears only in the excreta from birds given this material. Otherwise, the major components appear to be common to excreta from all three materials administered. The similarity in the pattern and amounts of excreta ${ }^{14} \mathrm{C}$-labelled compounds show that impurities alone did not account for the additional $10 \%$ of administered ${ }^{14} \mathrm{C}$ excreted by birds given DL- $\left[1-{ }^{14} \mathrm{C}\right] \mathrm{HMB}$. The results of both the oxidation and excretion studies suggest that birds metabolize L-methionine, D-methionine and DL-HMB differently.

Incorporation of ${ }^{14} \mathrm{C}$ from $\mathrm{L}$ - and DL- $\left[1-{ }^{14} \mathrm{C}\right]$ methionine and DL- $\left[1-{ }^{14} \mathrm{C}\right] \mathrm{HMB}$ into proteins of a number of tissues $6 \mathrm{~h}$ after administration is shown in Table $3,{ }^{14} \mathrm{C}$ incorporation differs with the precursor used and the different tissues responded in different ways towards each. The ${ }^{14} \mathrm{C}$ incorporation into liver proteins was equivalent from each of the three precursors, but in kidney there was a higher incorporation from $\mathrm{DL}-\left[1-{ }^{14} \mathrm{C}\right]$ methionine than from either of the other two precursors. This supports earlier conclusions from Fig. 3(a) and $(b)$ that the precursor pool (methionine and cysteine) for protein synthesis in liver and kidney is equally labelled with ${ }^{14} \mathrm{C}$ irrespective of the tracer given, except for $\mathrm{DL}-\left[1-{ }^{14} \mathrm{C}\right] \mathrm{methionine}$ which in kidney appears to produce a higher ${ }^{14} \mathrm{C}$ labelling in the protein precursor pool.

The differences between incorporation of ${ }^{14} \mathrm{C}$ from $\mathrm{DL}-\left[1-{ }^{14} \mathrm{C}\right] \mathrm{HMB}$ into protein of the tissues examined were not large. Although ${ }^{14} \mathrm{C}$ incorporation from $\mathrm{DL}-\left[1^{-{ }^{14}} \mathrm{C}\right] \mathrm{HMB}$ was generally lower, none of the differences were statistically significant (except for the special case in kidney as described previously; see Table 4). 


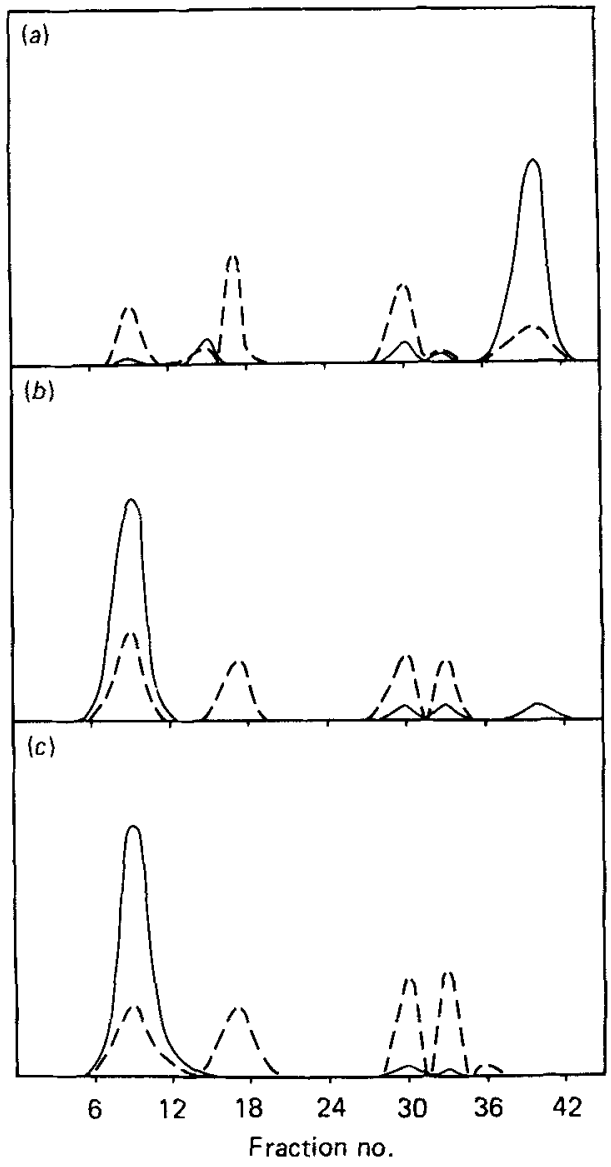

Fig. 4. Separation of ${ }^{14} \mathrm{C}$ labelled components in excreta. (a) DL-[1-14 C] 2-hydroxy 4-methylthiobutanoic acid (HMB), (b) DL- $\left[1-^{-14} \mathrm{C}\right]$ methionine, $(c)$ L-[1-14 C]methionine. $(\rightarrow$ Material injected (i.e. parent compound); (-- ) excreta components.

Table 3. Incorporation of ${ }^{14} C$ into tissue proteins from $L-\left[1-{ }^{14} C\right]$ methionine, $D L-\left[1-{ }^{14} C\right]-$ methionine and $D L-[1-14 C]$ 2-hydroxy 4-methylthiobutanoic acid $(H M B) 6 h$ after administration

(Values are expressed as counts/min per $\mathrm{g}$ wet tissue and are means with their standard errors for eight observations; statistical comparisons are shown in Table 4, p. 630)

\begin{tabular}{|c|c|c|c|c|c|c|}
\hline \multirow[b]{2}{*}{ Tissue } & \multicolumn{2}{|c|}{$\mathrm{L}-\left[1-{ }^{14} \mathrm{C}\right]$ methionine } & \multicolumn{2}{|c|}{ DL- $\left[1-{ }^{14} \mathrm{C}\right]$ methionine } & \multicolumn{2}{|c|}{ DL- $\left[1{ }^{14} \mathrm{C}\right] \mathrm{HMB}$} \\
\hline & Mean & SE & Mean & SE & Mean & SE \\
\hline Breast & 4249 & 407 & 2851 & 328 & 2218 & 153 \\
\hline Leg & 4169 & 595 & 2821 & 233 & 2640 & 232 \\
\hline Liver & 10973 & 1191 & 11690 & 746 & 11693 & 946 \\
\hline Kidney & 9721 & 904 & 12986 & 776 & 10308 & 809 \\
\hline Heart & 7770 & 945 & 5430 & 444 & 4849 & 249 \\
\hline Skin & 4540 & 764 & 2431 & 203 & 2036 & 137 \\
\hline Brain & 3468 & 644 & 1797 & 171 & 2037 & 163 \\
\hline
\end{tabular}


Table 4. Statistical comparisons of values for production of ${ }^{14} \mathrm{CO}_{2}$ and for excretion of ${ }^{14} \mathrm{C}$ material and ${ }^{14} \mathrm{C}$ incorporation into tissue proteins from $L-\left[1-{ }^{14} C\right]$ methionine, $D L-\left[1-{ }^{14} C\right]-$ methionine and $D L-\left[1-{ }^{14} \mathrm{C}\right]$ 2-hydroxy 4-methylthiobutanoic acid $(H M B) 6 h$ after administration (see Tables 1 and 2)

(Comparisons are made using Student's $t$ test and those given in parentheses by Mann-Whitney test)

\begin{tabular}{|c|c|c|c|}
\hline Treatments & $\begin{array}{c}\text { DL- }\left[1-{ }^{14} \mathrm{C}\right] \text { methionine } \\
y \text {. } \\
\mathrm{L}-\left[1-{ }^{14} \mathrm{C}\right] \text { methionine }\end{array}$ & $\begin{array}{c}\text { DL- }\left[1-{ }^{14} \mathrm{C}\right] \mathrm{HMB} \\
v . \\
\text { L- }\left[1-{ }^{14} \mathrm{C}\right] \text { methionine }\end{array}$ & $\begin{array}{c}\text { DL- }\left[1-{ }^{14} \mathrm{C}\right] \text { methionine } \\
v . \\
\text { DL- }\left[1{ }^{14} \mathrm{C}\right] \mathrm{HMB}\end{array}$ \\
\hline${ }^{14} \mathrm{CO}_{2}$ production & $*$ & NS & NS \\
\hline${ }^{14} \mathrm{C}$ in excreta & $* * *(* * *)$ & $* * *(* * *)$ & $* * *(* * *)$ \\
\hline \multicolumn{4}{|l|}{$\begin{array}{l}{ }^{14} \mathrm{C} \text { incorporation } \\
\text { into protein: }\end{array}$} \\
\hline Breast muscle & * & $* * *$ & NS \\
\hline Leg muscle & NS & * & NS \\
\hline Liver & NS & NS & NS \\
\hline Heart & NS $\left(^{*}\right)$ & $*(*)$ & NS (NS) \\
\hline Skin & $*(* *)$ & $*(* *)$ & NS (NS) \\
\hline Brain & $*(* *)$ & NS $\left({ }^{* *}\right)$ & NS (NS) \\
\hline
\end{tabular}

NS, not significant.

${ }^{*} P<0.05,{ }^{* *} P<0.01,{ }^{* * *} P<0.001$.

\section{DISCUSSION}

There is much controversy over the efficiency of HMB or MHA as a supplementary source of dietary methionine for chicks and laying hens receiving practical poultry feedstuffs. However, there seems to be little dispute that HMB is not as effective as DL-methionine in supporting growth in chicks given chemically-defined diets (e.g. Boebel \& Baker, 1982; van Weerden et al. 1982). A number of reasons have been suggested which may explain the discrepancy. Some authors (Katz \& Baker, 1975a; Boebel \& Baker, 1982; van Weerden et al. 1982,1983) suggest that the methionine : cysteine value and the degree of total sulphur amino acid deficiency of the basal diet used can confuse the comparison between DL-HMB and DL-methionine in experiments with practical feedstuffs. A number of workers (Tipton et al. 1966; Lerner et al. 1969; Baker, 1976) have speculated that DL-HMB is not as well absorbed from the intestinal tract as D- and L-methionine. Dibner \& Knight (1984b) have shown that L-methionine and DL-HMB are absorbed through the chick intestinal mucosa by different mechanisms. However, both compounds are absorbed rapidly at physiological concentrations in vivo and Dibner \& Knight (1984b) conclude that absorption would be unlikely to limit performance of birds given HMB in the feed. Preliminary work in this laboratory (Saunderson, 1983b) and the results of Saroka \& Combs (1983) agree with this conclusion.

Commercial preparations of DL-HMB (in the liquid-free acid-form) contain dimers, trimers and higher polymers of the hydroxy acid. This has led to the suggestion that the presence of the polymers (which may not be completely hydrolysed in vivo) (see Koban \& Koberstein, 1984) reduces the availability of DL-HMB to the bird for conversion to L-methionine (Boebel \& Baker, 1982; van Weerden et al. 1983).

The results presented here suggest another possible reason why DL-MHA and DLmethionine (D-methionine) differ in efficiency as a replacement for dietary L-methionine. Birds metabolize DL-HMB differently from L-methionine and probably from D-methionine and consequently DL-HMB, DL-methionine and L-methionine are excreted and incorporated 
into tissue proteins in different proportions. Although many reports suggest that D-methionine and L-methionine are nutritionally equivalent in chicks (e.g. Tipton et al. 1966), a report by Katz \& Baker (1975b) showed that, at low levels of supplementation, L-methionine was superior to $\mathrm{D}$-methionine.

There may also be differences in metabolism and nutritional efficiency of the $\mathrm{D}$ - and L-isomers of HMB. Baker \& Boebel (1980) found that D-HMB was more potent in supporting growth than the $L$-isomer using both soya-bean-protein-based and crystalline amino acid diets. Dibner \& Knight $(1984 b)$ have shown that the enzymes which oxidize the D- and L-forms of HMB to the $\alpha$-keto acid are quite distinct in their cellular location, cofactor requirements and tissue distribution. That the D-hydroxy acid dehydrogenase enzyme is more widely distributed in the body tissues suggests that, as Katz \& Baker (1975b) found, the $D$-isomer would be more effective as a methionine substitute. This finding may also explain why there is so little difference between the utilization of DL-methionine and DL-HMB in tissues other than liver and kidney. In both cases one of the isomers can be either used unchanged or converted in situ to L-methionine.

Differences in the extent of excretion of the three materials have not been previously reported. The amount of DL-HMB and DL-methionine (D-methionine) excreted represents a loss of potential L-methionine from the system. The lower incorporation ${ }^{2}{ }^{14} \mathrm{C}$ into proteins in tissues other than liver and kidney reflects this loss. Whether the excretion of significant amounts of $\mathrm{DL}-\left[1-{ }^{14} \mathrm{C}\right] \mathrm{HMB}$ and $\mathrm{D}-\left[1-{ }^{14} \mathrm{C}\right]$ methionine is due to inefficiency of the bird in using those materials or whether the excretion pattern leads to less material for protein incorporation cannot be judged from these results alone. The results differ from those reported by Gordon \& Sizer (1965), although in their study the tracer used, strain of bird and time of collection were all different from the present work.

Little is known of the excretion of hydroxy acids by chicks, although Gordon \& Sizer (1965) discuss work which suggests that the hydroxy acid (but not the keto acid) analogue of methionine can be actively re-absorbed in the kidney. Excretion of D-methionine by chicks is not well documented, but studies with humans and monkeys have shown that only D-methionine is excreted when DL-methionine is administered (Kies et al. 1975; Stegink et al. 1980). Earlier studies on mammals led to the suggestion that this is due to active re-absorption of L-methionine in the proximal tubule of the kidney (Crampton \& Smyth, 1953). Our results suggest another explanation for such differential excretion in chicks. DL-HMB (Fig. 2(a)) and DL-methionine (results not shown) accumulate in the non-protein fraction of chick kidney, while L-methionine does not (Fig. 2(a)). Such an accumulation of DL-HMB and D-methionine in kidney leads to elevated excretion compared with L-methionine.

The accumulation of DL-HMB and D-methionine in kidney also indicates that there is a link between the need for conversion of these materials to L-methionine and excretion. Studies in a number of laboratories (Baker, 1952; Tubbs \& Greville, 1961 ; Gordon \& Sizer, 1965; Langer, 1965) as well as the results presented here suggest that kidney is an important site for conversion of D-methionine, D-and L-HMB to L-methionine. Elevated levels of DL-HMB and D-methionine in kidney are beneficial for conversion to L-methionine but unfortunately also encourage excretion.

It is most surprising that there is relatively little difference in oxidation of the three precursors and also that the level of catabolism is so low. This is especially surprising since the same intermediate, 2-keto 4-methylthiobutyric acid, is common to both oxidation of L-methionine and conversion of D-methionine and D- and L-HMB to L-methionine. Catabolism of methionine in the rat takes place primarily in liver and kidney (Mitchell \& Benevenga, 1978) and this also appears to be the case in the chick (C. L. Saunderson, unpublished results). Yet the large differences in distribution of the three tracer materials 
in kidney do not lead to differences in oxidation. Without a further investigation of the enzymes involved it is difficult to say what controls the rate of 2-keto 4-methylthiobutyrate formation from each of the precursors or the partitioning of this metabolite between the various pathways available to it.

The incorporation of ${ }^{14} \mathrm{C}$ into tissue proteins reflects the substantial excretion of DL- $\left[1-{ }^{14} \mathrm{C}\right] \mathrm{HMB}$ and DL- $\left[1-{ }^{14} \mathrm{C}\right]$ methionine. Skeletal muscles, heart, skin and brain all show much lower ${ }^{14} \mathrm{C}$ incorporation from DL- $\left[1-{ }^{14} \mathrm{C}\right] \mathrm{HMB}$ and $\mathrm{DL}-\left[1-{ }^{14} \mathrm{C}\right]$ methionine than from $\mathrm{L}-\left[1-{ }^{14} \mathrm{C}\right]$ methionine. Liver and kidney behave differently from other tissues in that ${ }^{14} \mathrm{C}$ incorporation from DL- $\left[1-{ }^{14} \mathrm{C}\right] \mathrm{HMB}$ and $\mathrm{DL}-\left[1-{ }^{14} \mathrm{C}\right]$ methionine is not lower than that from $\mathrm{L}-\left[1-{ }^{14} \mathrm{C}\right]$ methionine. In kidney the incorporation of ${ }^{14} \mathrm{C}$ into protein did not differ whether $\mathrm{L}-\left[1-{ }^{14} \mathrm{C}\right]$ methionine or DL- $\left[1-{ }^{14} \mathrm{C}\right] \mathrm{HMB}$ was injected yet the ${ }^{14} \mathrm{C}$ in the PCA-soluble fraction of this tissue was very much higher from DL- $\left[1-{ }^{14} \mathrm{C}\right] \mathrm{HMB}$ (Fig. 2(a)). This implies that the majority of ${ }^{14} \mathrm{C}$ material present derived from $\mathrm{DL}-\left[1-{ }^{14} \mathrm{C}\right] \mathrm{HMB}$ appearing in the non-protein fraction was not in the form of L-methionine. On the other hand, liver tissue showed only a slightly higher amount of ${ }^{14} \mathrm{C}$ from $\mathrm{L}-\left[1-{ }^{14} \mathrm{C}\right] \mathrm{HMB}$ in the PCA-soluble fraction. This suggests that, in liver, most of the labelled material is present as L-methionine (or cysteine). These results indicate that metabolism of DL- $\left[1-{ }^{14} \mathrm{C}\right] \mathrm{HMB}$ differs in liver and kidney, liver having a higher proportion of DL-HMB converted to L-methionine. The reason for this difference cannot be deduced from these studies and an examination of the metabolic pathways and their activities in these tissues would be required. Larbier \& Perrot (1984) also showed that HMB is efficiently converted to L-methionine in liver tissue. In their experiments they found higher levels of ${ }^{14} \mathrm{C}$ in liver proteins from birds given $\mathrm{DL}-\left[1-{ }^{14} \mathrm{C}\right] \mathrm{HMB}$ than from either L-or DL-[1-14 C]methionine.

Despite the presence of D-hydroxy acid dehydrogenase in tissues other than liver and kidney (see earlier discussion and Dibner \& Knight, 1984a), our results show that utilization of DL-HMB takes place principally in the liver and kidney of the chick. Peripheral tissues showed similar amounts of ${ }^{14} \mathrm{C}$ in the acid-soluble cell fraction (Fig. 2 and Table 1) yet lower ${ }^{14} \mathrm{C}$ incorporated into cell proteins. Larbier \& Perrot (1984) showed a similar situation for breast muscle tissue over a $24 \mathrm{~h}$ period,

The difficulty with the non-normality of the values for ${ }^{14} \mathrm{C}$ incorporation into heart, skin and brain proteins may also be a consequence of the distribution of the oxidase (and transaminase) enzymes which convert DL-methionine and D- and L-HMB to L-methionine. It is possible that chicks have a genetically-produced variability in the levels of these enzymes in these tissues. It is clear, however, that neither D-methionine nor D- and L-HMB are as efficient as L-methionine as protein precursors in heart, skin and brain. This is especially obvious when the non-normality of the values is accounted for statistically (Table 4).

Since tissues other than liver and kidney represent a far larger proportion of body protein they therefore provide a more important gauge of the effectiveness of DL-methionine or $\mathrm{DL}-\mathrm{HMB}$ as a replacement for L-methionine in the diet. The results presented here suggest that studies on one tissue alone (especially liver or kidney) cannot give a proper indication of protein incorporation rates in other body tissues. Therefore previous studies which used liver tissue only (Gordon \& Sizer, 1965; Dibner, 1983) could not adequately compare the efficiency of L-methionine and DL-MHA as precursors for whole-body protein synthesis.

The author would like to express thanks to Dr F. J. Ivey, Monsanto Company, St Louis, Missouri, USA for the very kind gift of $\mathrm{DL}-\left[1-{ }^{14} \mathrm{C}\right] \mathrm{HMB}$. Thanks are also due to $\mathrm{Mr}$ D. Greenhill and Mr S. Leslie for excellent technical assistance, Dr M. MacLeod for advice on the construction of the metabolism chamber, to $\mathrm{Mr} \mathrm{D}$. Waddington for assistance with statistical analyses and to Dr C. Fisher for useful discussion. 


\section{REFERENCES}

Baker, C. G. (1952). Archives of Biochemistry and Biophysics 41, 325-332.

Baker, D. H. (1976). Federation Proceedings 35, 1917-1922.

Baker, D. H. \& Boebel, K. P. (1980). Journal of Nutrition 110, 959-964.

Bird, F. (1952). Poultry Science 31, 1095-1096.

Boebel, K. P. \& Baker, D. H. (1982). Poultry Science 61, 1167-1175.

Bolton, W. \& Blair, R. (1974). Poultry Nutrition Bulletin no. 174, 4th ed. London: H.M. Stationery Office.

Christensen, A. C., Anderson, J. O. \& Dobson, D. C. (1980). Poultry Science 59, $2480-2484$.

Crampton, R. F. \& Smyth, D. H. (1953). Journal of Physiology 122, 1-10.

Dibner, J. J. (1983). Journal of Nutrition 113, $2116-2123$.

Dibner, J. J. \& Knight, C. D. (1984a). Journal of Nutrition 114, 1716-1723.

Dibner, J. J. \& Knight, C. D. (1984b). Journal of Nutrition 114, 2179-2186.

Featherston, W. R.\& Horn, G. W. (1974). Poultry Science 53, 680-686.

Gordon, R. S. \& Sizer, I. W. (1955). Poultry Science 34, 1198.

Gordon, R. S. \& Sizer, I. W. (1965). Poultry Science 44, 673-678.

Jeffay, H.\& Alvarez, J. (1961). Analytical Chemistry 33, 612-615.

Katz, R. S. \& Baker, D. H. (1975a). Poultry Science 54, 584-591.

Katz, R. S. \& Baker, D. H. (1975b). Poultry Science 54, 1667-1674.

Kies, C., Fox, H. \& Aprahamian, S. (1975). Journal of Nutrition 105, 809-814.

Koban, H. G. \& Koberstein, E. (1984). Journal of Agricultural and Food Chemistry 32, 393-396.

La Noue, K., Nicklas, W. J. \& Williamson, J. R. (1970). Journal of Biological Chemistry 245, $102-111$.

Langer, B. W. (1965). Biochemical Journal 95, 683-687.

Larbier, M. \& Perrot, I. (1984). Archive für Geflugelkunde 48, 113-116.

Lerner, J., Yankelowitz, S. \& Taylor, M. W. (1969). Experientia 25, 689-691.

Mitchell, A. D. \& Benevenga, N. J. (1978). Journal of Nutrition 108, 67-78.

Reid, B. L., Madrid, A. \& Maiorino, P. H. (1982). Poultry Science 61, 726-730.

Saroka, J. M. \& Combs, G. F. (1983). Poultry Science 62, 1496.

Saunderson, C. L. (1983a). European Association of Animal Production IVth International Symposium on Protein Metabolism and Nutrition, INRA publication no. 16; vol. 2, pp. $41-44$. Paris, France: INRA.

Saunderson, C. L. (1983b). Proceedings of the Nutrition Society 42, 139A.

Smith, R. E. (1966). Poultry Science 45, 571-577.

Spydevold, Ø. (1979). European Journal of Biochemistry 97, 389-394.

Stegink, L. D., Moss, J., Printen, K. \& Cho, E. S. (1980). Journal of Nutrition 110, 1240-1246.

Tipton, H. C., Dilworth, B. C. \& Day, E. J. (1966). Poultry Science 45, 381-387.

Tubbs, P. K. \& Greville, G. D. (1961). Biochemical Journal 81, 104-114.

van Weerden, E. J., Bertram, H. L. \& Schutte, J. B. (1982). Poultry Science 61, 1125-1130.

van Weerden, E. J., Schutte, J. B. \& Bertram, H. L. (1983). Poultry Science 62, 1269-1274. 